HETEROCYCLES, Vol. 63, No. 3, 2004, pp. 681 - 690

Received, 14th November, 2003, Accepted, 8th January, 2004, Published online, 19th January, 2004

\title{
DIASTEREOSELECTIVE SYNTHESIS OF SUBSTITUTED 2-PHENYLTETRAHYDROPYRANS AS USEFUL PRECURSORS OF ARYL C-GLYCOSIDES VIA SELENOETHERIFICATION
}

\section{Michelangelo Gruttadauria,* Carmela Aprile, Paolo Lo Meo, Serena Riela, and Renato Noto}

\author{
Department of Organic Chemistry "E. Paternò", University of Palermo, Viale \\ delle Scienze, Parco d'Orleans II, 90128 Palermo, Italy. E-mail: mgrutt@,unipa.it.
}

\begin{abstract}
The cyclization of several substituted 5-phenyl-pent-4-en-1-ols with selenium electrophiles along some mechanistic considerations is discussed. In particular, an efficient diastereoselective synthesis of a 2,3,5,6-tetrasubstitued tetrahydropyran is reported. These findings open an interesting approach: the use of chiral selenium electrophiles for cyclization of chiral substrates. The cyclized products are useful starting material for the synthesis of D- or L-aryl $C$-glycosides.
\end{abstract}

Aryl C-glycosides are naturally-occurring, structurally diverse compounds that have attracted considerable attention because they exhibit a vast array of important biological activities. ${ }^{1}$ In particular they are able to form stable complexes with DNA. ${ }^{2}$ Molecular recognition involving van der Waals and/or hydrogen bonding interactions between the sugar substituent and the DNA helix is implicated. Recently, several C-glycoside derivatives have been found to possess binding constants and biological properties very similar to those of their oxygen counterparts. ${ }^{3}$ The absence of an oxygen atom between the carbohydrate and the aryl moiety results in greater stability of these compounds when compared to $O$-glycosides. Indeed, they are very stable to acidic hydrolysis and less vulnerable to enzymatic digestion. $^{4}$

Since $C$-glycosides that do not occur in nature, but that are congeners of biologically important $O$-glycosides may eventuate in the discovery of lead compounds having novel biological activities and pharmaceutical value, there have been a wealth of synthetic approaches toward this class of 
carbohydrate mimics. ${ }^{5,6}$ Usually, aryl $C$-glycosides are prepared by transformation of a functionalised carbohydrate with an aryl group at the anomeric position ${ }^{7}$ or by a de novo synthesis. ${ }^{8}$ An interesting de novo approach is the 6-endo selenoetherification of substituted (E)-5-arylpent-4-en-1-ols. ${ }^{8 \mathrm{~d}-\mathrm{f}}$ Indeed, the reductive elimination of the selenides affords deoxy-aryl $C$-glycosides whereas oxidative elimination affords dihydropyrans that can be transformed into aryl $C$-glycosides by further dihydroxylation (Figure 1).<smiles>[R]C1CC([Al])OC([Al])C1</smiles>

Figure 1. (i) reductive elimination; (ii) oxidative elimination.

Recently, ${ }^{9}$ we devoted our efforts to the diastereoselective synthesis of oxygenated heterocyclic rings such as lactones, tetrahydropyrans and tetrahydrofurans using the selenium chemistry. Moreover, in the last decade several authors have developed new chiral organoselenium compounds for the enantioselective synthesis of the aforesaid heterocyclic rings. ${ }^{10}$ Such chiral compounds are able to transfer their chirality into the substrate because of the intramolecular $\mathrm{X}-\mathrm{-Se}(\mathrm{X}=\mathrm{O}, \mathrm{N}, \mathrm{S})$ interaction.

Here we report some results on the diastereoselective synthesis of 2-aryl-substituted tetrahydropyrans as precursors for aryl $C$-glycosides along with some mechanistic considerations.

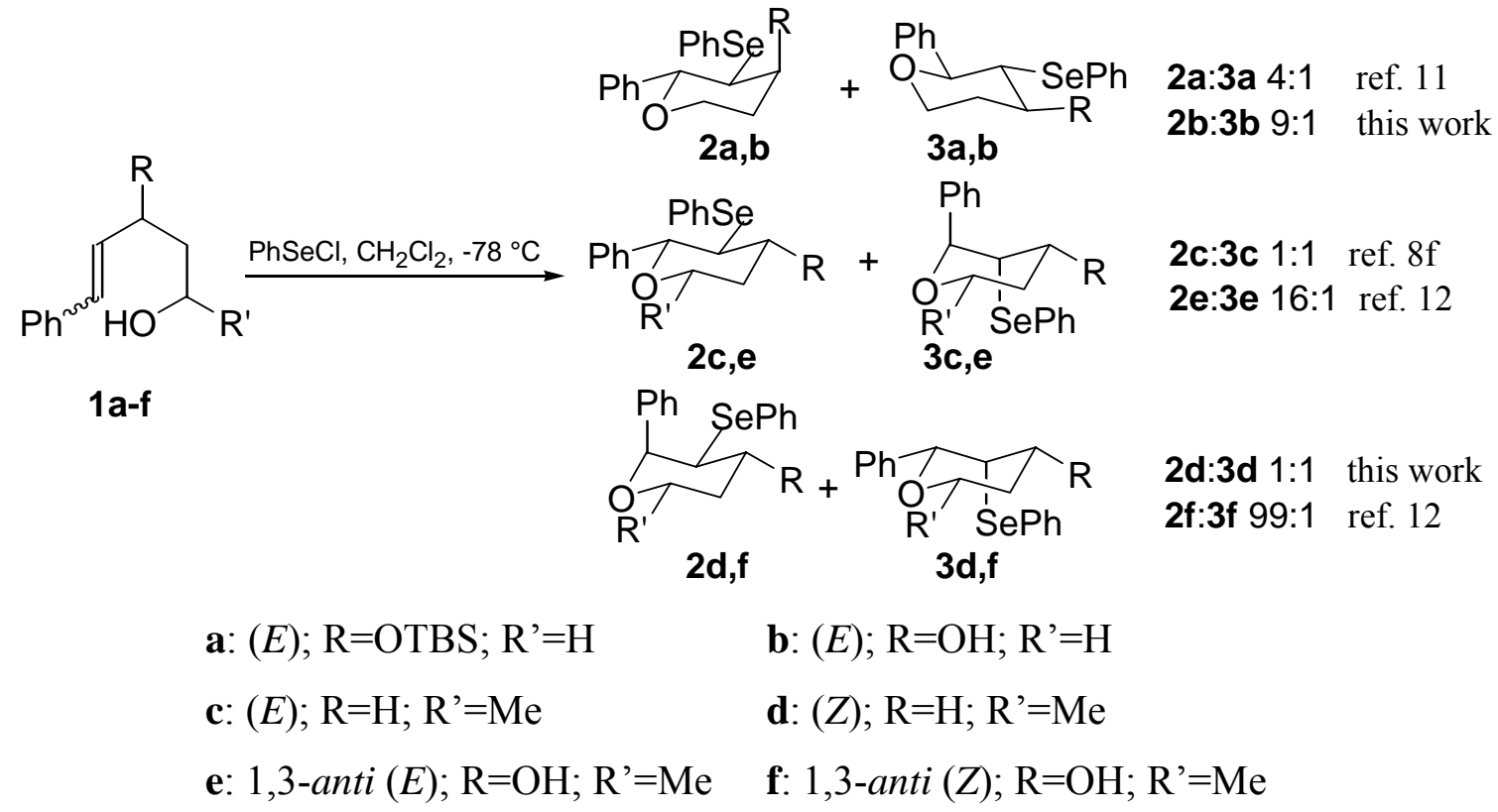

\section{Scheme 1}

First we overviewed the behaviour of compounds (1) in order to complete the literature data. Hart ${ }^{11}$ reported that compound (1a) gave, as preferred product, the corresponding tetrahydropyran having the 4-OR group in axial position, invoking for such result the deactivating effect of the OR group when equatorially disposed. However, we believe that this preference arise from the stabilizing Se--O 
interaction during the course of the cyclization. For this reason we studied the cyclization of compound (1b). We found higher diastereoselectivity (9:1) compared to 1a (4:1) in agreement with the higher coordination effect of the unprotected $\mathrm{OH}$ group. We argued that intramolecular stabilizing Se--O interaction is important in determining a high diastereoselectivity. As confirmation of this hypothesis cyclization of $\mathbf{1} \mathbf{c}^{8 \mathrm{f}}$ and 1d gave mixture of diastereoisomers without selectivity. Moreover, we carried out the cyclization of $\mathbf{1 b}$ in the presence of silica gel. This reaction gave low diastereoselectivity (2:1) according to the fact that the $\mathrm{OH}$ groups of silica give strong interactions with positively charged selenium atom destroying the intramolecular Se--O interaction. ${ }^{12}$ These results, together with the high diastereoselectivities observed in the cyclization of compounds $(\mathbf{1 e , f}){ }^{12}$ are a clear evidence of the important role played by the $\mathrm{OH}$ group in allylic position on the diastereoselectivity.

We, then, investigated the behaviour of compounds (7a,b) where the OR group was moved to the homoallylic position. The absence of a substituent in allylic position should lead to a low diastereoselectivity. Compounds (7a,b) were prepared as outlined in the Scheme 2.

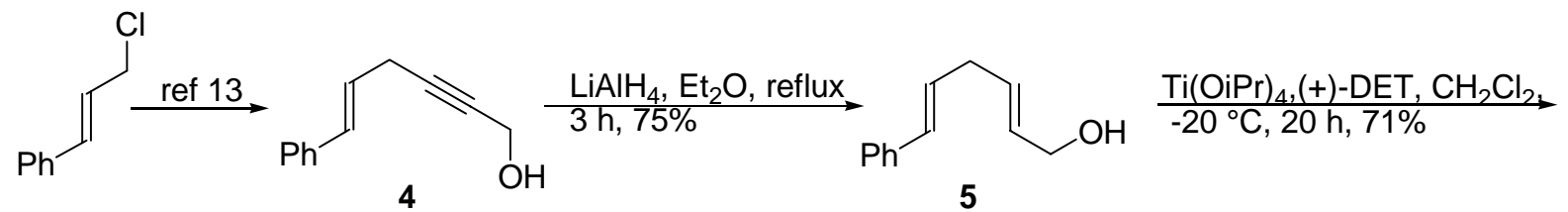

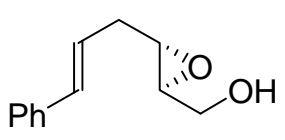

6

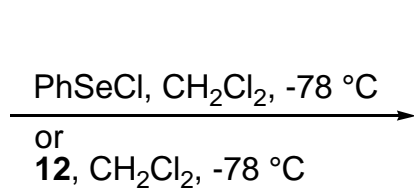

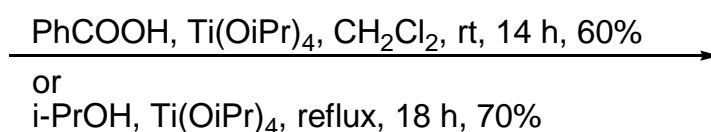

i-PrOH, Ti(OiPr) 4 , reflux, 18 h, 70\%

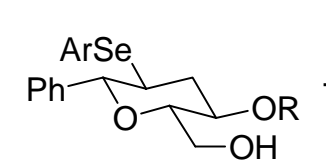

$8 a, b$
$10 a, b$

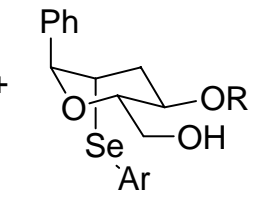

$9 a, b$

$11 a, b$<smiles>[R]OC(CO)[C@H]([O])C/C=C\c1ccccc1</smiles>

$7 a, b$

a: $\mathrm{R}=\mathrm{COPh}$

b: $\mathrm{R}=i-\mathrm{Pr}$

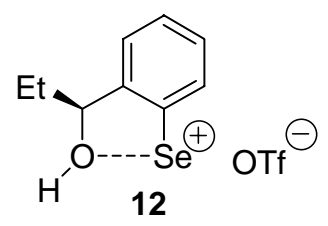

8,9: $\mathrm{Ar}=\mathrm{Ph} ; \mathbf{1 0 , 1 1 :} \mathrm{Ar}=\mathrm{Et}_{\mathrm{OH}}^{\mathrm{H}}$

\section{Scheme 2.}

Reduction with $\mathrm{LiAlH}_{4}$ gave 5 that was submitted to Sharpless epoxidation conditions to give 6 in $71 \%$ yield and $90 \%$ e.e. Epoxide ring opening was carried out with benzoic acid ${ }^{14}$ or 2-propanol ${ }^{15}$ in the presence of $\mathrm{Ti}(\mathrm{OiPr})_{4}$ to give $\mathbf{7 a}$ and $\mathbf{7 b}$ respectively with good regioselectivity $(90 / 10$ for $\mathbf{7 a}$; $93 / 7$ for 7b). Cyclization of 7a with $\mathrm{PhSeCl}$ in $\mathrm{CH}_{2} \mathrm{Cl}_{2}$ at $-78{ }^{\circ} \mathrm{C}$ gave 8a and 9a in 60:40 ratio (74\% yield). The reaction was highly regioselective but, as expected, without diastereoselectivity. Compound (7b) also gave similar results, (8b:9b 67:33; 80\% yield). The behaviour of compounds (7a,b) resembles that of $\mathbf{1 c}$. In these substrates the attack from the Re or Si face lead to seleniranium ions similar in energy, moreover also their transition states (13) and (14) should be similar in energy. The presence of an 
additional group in axial position in $\mathbf{1 4}\left(\mathrm{R}_{1}=\mathrm{OCOPh}\right.$ or $\mathrm{OiPr} ; \mathrm{R}_{2}=\mathrm{OH}$ in comparison with $\left.\mathrm{R}_{1}=\mathrm{R}_{2}=\mathrm{H}\right)$ is evidently not sufficient to cause severe steric interactions (see Scheme 3).

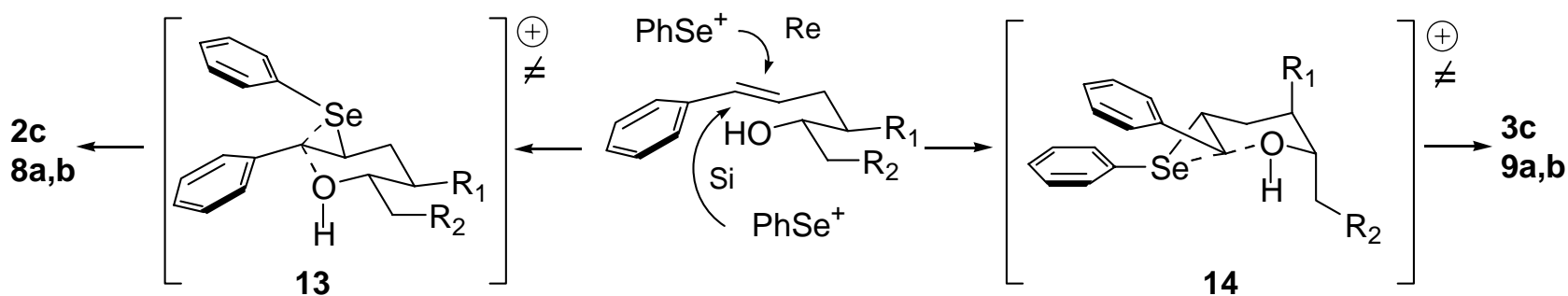

Scheme 3. Transition states for cyclization of compounds (1c) and (7a,b) with $\mathrm{PhSeCl}$.

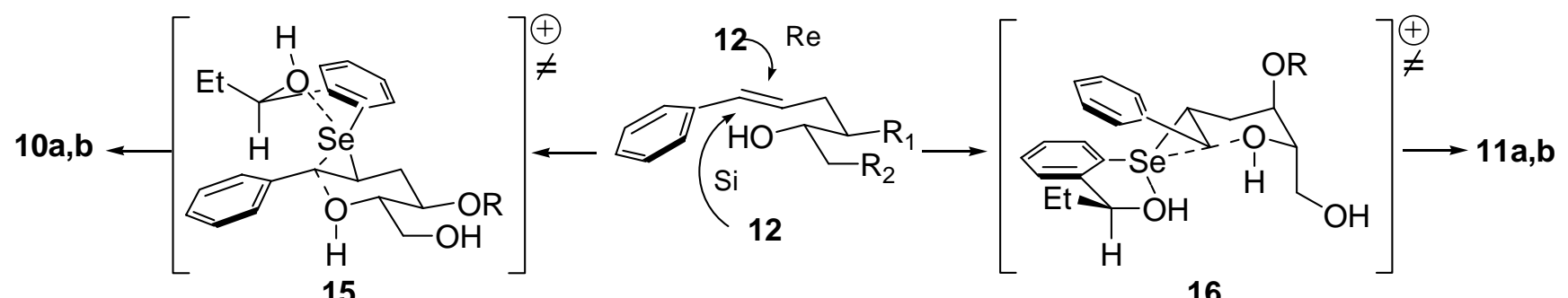

Scheme 4. Transition states for cyclization of compounds (7a,b) with (12).

We reasoned that a chiral organoselenium reagent could increase the diastereoselectivity. Indeed, the attack from the Re and Si faces should give seleniranium ions with different stability; moreover, the chirality of the organoselenium reagent should increase the difference in energy of the corresponding transition states.

We decided to use reagent (12) prepared by Wirth, ${ }^{16}$ one of the simplest chiral organoselenium electrophiles. The mechanism of the stereoselective selenenylation reactions with $\mathbf{1 2}$ has been the subject of three works. ${ }^{17}$

Compound (7a) gave a complex reaction crude from which we were able to isolate the major diastereoisomer in modest yield (30\%). However, the diastereoselectivity was certainly higher with respect to the corresponding reaction with the achiral selenium reagent, since the minor diastereoisomer was detected in mixture with other minor not identified product giving, at last, a roughly 80:20 ratio. Compound (7b) gave a better result. Both yield and diastereoselectivity ${ }^{18}$ were high (79\%; 93:7 10b:11b). We also recovered some starting material (10\%), having the same e.e. ${ }^{19}$ These results are in agreement with Wirth's findings: the attack from the Si face on aryl-substituted double bonds is less favourable. Moreover, we believe that transition state (16), compared to 15, experiences more severe steric interactions than $14\left(\mathrm{R}_{1}=\mathrm{OiPr} ; \mathrm{R}_{2}=\mathrm{OH}\right)$ (see Scheme 4).

In conclusion we have showed how the substituents of several 5-phenylpent-4-en-1-ols affect the diastereoselectivity in the cyclization reactions. Moreover, we have reported the first example of the use of a chiral organoselenium electrophile for diastereoselective cyclization of a chiral substrate. ${ }^{20}$ This 
approach allows the stereoselective synthesis of precursors of both $\mathrm{D}$ - and L-aryl $C$-glycosides depending on the Sharpless epoxidation. In particular the de novo synthesis of L-aryl C-glycosides is of interest since they are less available by transformation of a naturally occurring carbohydrate.

\section{EXPERIMENTAL}

General. Methylene chloride and diethyl ether were distilled prior to use. Reactions were routinely carried out under argon with magnetic stirring. IR spectra were recorded on a Shimadzu FTIR 8300 spectrophotometer. ${ }^{1} \mathrm{H}$ NMR and ${ }^{13} \mathrm{C}$ NMR (COSY and HETCOR) spectra were recorded on a Bruker AC-E series $250 \mathrm{MHz}$ spectrometer in $\mathrm{CDCl}_{3}$ solution. Silica gel (Macherey-Nagel, 0.04-0.063 mm) was used for column chromatography.

\section{(1RS, 5Z)-6-Phenylhex-5-en-2-ol (1d)}

To a solution of (1RS)-6-phenylhex-5-yn-2-ol ${ }^{8 \mathrm{f}}(160 \mathrm{mg}, 0.925 \mathrm{mmol})$ in ethanol $(15 \mathrm{~mL})$ containing ethylenediamine $(15 \mu \mathrm{L})$ was added Lindlar catalyst $(16 \mathrm{mg})$. Hydrogen was allowed to flow through the solution ( $1 \mathrm{~atm}, 50 \mathrm{NmL} / \mathrm{min})$. After $4 \mathrm{~h}$ the reaction mixture was filtered and the solvent removed under reduced pressure. The residue was chromatographed on silica gel, using light petrol ether (4:1) as eluent to give 1d as oil (155 mg, yield 97\%). ${ }^{1} \mathrm{H}$ NMR: $\delta 1.19(\mathrm{~d}, \mathrm{~J}=6.2 \mathrm{~Hz}, 3 \mathrm{H}), 1.54-1.67$ (m, 2H), 2.03 (br s, $1 \mathrm{H}), 2.37-2.51(\mathrm{~m}, 2 \mathrm{H}), 3.79-3.99(\mathrm{~m}, 1 \mathrm{H}), 5.69(\mathrm{dt}, \mathrm{J}=11.7$ and $7.3 \mathrm{~Hz}, 1 \mathrm{H}), 6.48(\mathrm{dt}, \mathrm{J}=11.7 \mathrm{and} 1.6 \mathrm{~Hz}$, 1H), 7.22-7.40 (m, 5H); ${ }^{13} \mathrm{C}$ NMR: $\delta 23.3,24.8,39.0,67.4,126.5,128.1,128.6,129.1,132.2,137.4$. IR (liquid film): $3356 \mathrm{~cm}^{-1}$. Anal. Calcd for $\mathrm{C}_{12} \mathrm{H}_{16} \mathrm{O}: \mathrm{C}, 81.77$; H, 9.15. Found: C, 81.80; H, 9.21.

\section{(2E, 5E)-6-Phenylhexa-2,5-dien-1-ol (5)}

To a solution of $4(1.14 \mathrm{~g}, 6.61 \mathrm{mmol})$ in ether $(59 \mathrm{~mL})$ at $0{ }^{\circ} \mathrm{C}$ a solution of $\mathrm{LiAlH}_{4}$ in ether $(4 \mathrm{~mL}, 4.00$ mmol) was slowly added. The resulting solution was then stirred under reflux at $35{ }^{\circ} \mathrm{C}$. After $3 \mathrm{~h}$ to the reaction mixture water $(148 \mu \mathrm{L}), 15 \%$ aqueous $\mathrm{NaOH}(148 \mu \mathrm{L})$ and water $(445 \mu \mathrm{L})$ were sequentially added. The reaction mixture was warmed to rt, dried on anhydrous sodium sulfate, filtered on celite, and the solvent was then removed under reduced pressure. The residue was chromatographed on silica gel, using light petrol ether $(4: 1)$ as eluent to give 5 as oil $(855 \mathrm{mg}$, yield $75 \%)$. ${ }^{1} \mathrm{H}$ NMR: $\delta 2.98$ (dd, $\mathrm{J}=6.0$ and $6.0 \mathrm{~Hz}, 2 \mathrm{H}), 4.14(\mathrm{~d}, \mathrm{~J}=4.2 \mathrm{~Hz}, 2 \mathrm{H}), 5.68-5.86(\mathrm{~m}, 2 \mathrm{H}), 6.22(\mathrm{dt}, \mathrm{J}=15.8$ and $6.5 \mathrm{~Hz}, 1 \mathrm{H}), 6.42(\mathrm{~d}$, $\mathrm{J}=15.8 \mathrm{~Hz}, 1 \mathrm{H}), 7.18-7.39(\mathrm{~m}, 5 \mathrm{H}) ;{ }^{13} \mathrm{C}$ NMR: $\delta 35.3,63.1,125.8,126.9,127.9,128.3,130.1,130.2$, 130.7, 137.3. IR (liquid film): $3338 \mathrm{~cm}^{-1}$. Anal. Calcd for $\mathrm{C}_{12} \mathrm{H}_{14} \mathrm{O}: \mathrm{C}, 82.72 ; \mathrm{H}, 8.10$. Found: $\mathrm{C}, 82.80 ; \mathrm{H}$, 8.13 .

\section{(2S, 3S, 5E)-2,3-Oxirane-6-phenylhex-5-en-1-ol (6)}

At $-20{ }^{\circ} \mathrm{C} \operatorname{Ti}(\mathrm{OiPr})_{4}(820 \mu \mathrm{L}, 2.76 \mathrm{mmol})$ and L-(+)-DET $(557 \mu \mathrm{L}, 2.76 \mathrm{mmol})$ were added to $\mathrm{CH}_{2} \mathrm{Cl}_{2}$ $\left(23 \mathrm{~mL}\right.$ ) and allowed to stir for $5 \mathrm{~min}$. Compound (5) (400 mg, $2.3 \mathrm{mmol}$ ) dissolved in $\mathrm{CH}_{2} \mathrm{Cl}_{2} \mathrm{~mL}$ was then 
added via cannula. Last, TBPH $(840 \mu \mathrm{L}, 4.6 \mathrm{mmol})$ was added. The solution was allowed to stir at $-20{ }^{\circ} \mathrm{C}$ for about $20 \mathrm{~h}$. The reaction was then quenched with an aqueous $10 \%$ solution of tartaric acid $(6 \mathrm{~mL})$. The reaction mixture was warmed to $\mathrm{rt}$ and allowed to stir for $1 \mathrm{~h}$. The organic phase was separated, washed with aqueous saturated $\mathrm{NaCl}$ solution, dried on anhydrous sodium sulfate, and finally concentrated under reduced pressure. The resulting yellow oil was purified by column chromatography on silica gel, using light petrol-ethyl acetate (4:1) as eluent to give 6 as oil (308 mg, yield 71\%). ${ }^{1} \mathrm{H}$ NMR: $\delta 2.44$ (br s, $\left.1 \mathrm{H}\right)$, 2.50-2.55 (m, 2H), 3.00-3.05 (m, 1H), 3.10-3.16 (m, 1H), $3.64(\mathrm{dd}, \mathrm{J}=12.6$ and $4.5 \mathrm{~Hz}, 1 \mathrm{H}), 3.94(\mathrm{dd}$, $\mathrm{J}=12.6$ and $2.4 \mathrm{~Hz}, 1 \mathrm{H}), 6.21(\mathrm{dt}, \mathrm{J}=15.9$ and $6.9 \mathrm{~Hz}, 1 \mathrm{H}), 6.51(\mathrm{~d}, \mathrm{~J}=15.9 \mathrm{~Hz}, 1 \mathrm{H}), 7.19-7.39(\mathrm{~m}, 5 \mathrm{H}) ;{ }^{13} \mathrm{C}$

NMR: $\delta 34.6,34.9,38.0,61.4,124.1,125.9,127.2,128.3,132.6,136.9$. IR (liquid film): $3411 \mathrm{~cm}^{-1}$. Anal. Calcd for $\mathrm{C}_{12} \mathrm{H}_{14} \mathrm{O}_{2}$ : C, 75.76; H, 7.42. Found: C, 75.80; H, 7.50.

\section{(2S, 3R, 5E)-3-Benzoyloxy-6-phenylhex-5-ene-1,2-diol (7a)}

To a solution of compound (6) $(143 \mathrm{mg}, 0.753 \mathrm{mmol})$ in $\mathrm{CH}_{2} \mathrm{Cl}_{2}(3.76 \mathrm{~mL})$ at $0{ }^{\circ} \mathrm{C}, \mathrm{PhCOOH}(138 \mathrm{mg}$, $1.13 \mathrm{mmol})$ and $\mathrm{Ti}(\mathrm{OiPr})_{4}(222 \mu \mathrm{L}, 0.753 \mathrm{mmol})$ were added. The resulting solution was allowed to stir at $0{ }^{\circ} \mathrm{C}$ for $1 \mathrm{~h}$ and then at $\mathrm{rt}$ for $20 \mathrm{~h}$. The reaction was quenched with saturated aqueous $\mathrm{NaHCO}_{3}$, and subsequently extracted with $\mathrm{CH}_{2} \mathrm{Cl}_{2}$. The organic layer was washed with saturated aqueous $\mathrm{NaCl}$, dried on anhydrous sodium sulfate and concentrated under reduced pressure. The crude material was purified by column chromatography on silica gel using light petrol-ethyl acetate (2:1) as eluent to give 7a as oil (141 mg, yield $60 \%$ ). ${ }^{1} \mathrm{H}$ NMR: $\delta$ 2.72-2.87 (m, 2H), 3.50 (br s, 2H), 3.68 (dd, J=11.9 and 5.1 Hz, 1H), $3.79(\mathrm{dd}, \mathrm{J}=11.9$ and $2.2 \mathrm{~Hz}, 1 \mathrm{H}), 3.85-3.93(\mathrm{~m}, 1 \mathrm{H}), 5.21-5.29(\mathrm{~m}, 1 \mathrm{H}), 6.25(\mathrm{dt}, \mathrm{J}=15.8 \mathrm{and} 7.3 \mathrm{~Hz}, 1 \mathrm{H})$, $6.53(\mathrm{~d}, \mathrm{~J}=15.8 \mathrm{~Hz}, 1 \mathrm{H}), 7.19-7.61(\mathrm{~m}, 8 \mathrm{H}), 8.03-8.07$ (m, 2H); ${ }^{13} \mathrm{C}$ NMR: $\delta 34.3,62.6,72.3,73.9,124.6$, 126.0, 127.1, 128.3, 129.5, 129.6, 133.3, 133.4, 137.1, 166.8. IR (liquid film): 3415, $1714 \mathrm{~cm}^{-1}$. Anal. Calcd for $\mathrm{C}_{19} \mathrm{H}_{20} \mathrm{O}_{4}$ : C, 73.06; H, 6.45. Found: C, 73.20; H, 6.50.

\section{(2S, 3R, 5E)-3-i-Propoxy-6-phenylhex-5-ene-1,2-diol (7b)}

To a solution of compound (6) $(490 \mathrm{mg}, 2.58 \mathrm{mmol})$ in $i-\mathrm{PrOH}(25.8 \mathrm{~mL}) \mathrm{Ti}(\mathrm{OiPr})_{4}(1.15 \mathrm{~mL}, 3.87$ mmol) were added. The resulting solution was refluxed at $80{ }^{\circ} \mathrm{C}$ for $18 \mathrm{~h}$. The reaction was quenched adding ether and aqueous $5 \% \mathrm{H}_{2} \mathrm{SO}_{4}$, and allowed to stand until the two phases were distinctly separated (about $2 \mathrm{~h}$ ). The organic layer was separated, while the aqueous layer was extracted with diethyl ether. The collected organic phases were washed with saturated aqueous $\mathrm{NaCl}$, dried on anhydrous sodium sulfate and concentrated under reduced pressure. The crude material was purified by column chromatography on silica gel using light petrol-ethyl acetate (3:1) as eluent to give $\mathbf{7 b}$ as oil (450 $\mathrm{mg}$, yield $70 \%$ \%). ${ }^{1} \mathrm{H}$ NMR: $\delta 1.15(\mathrm{~d}, \mathrm{~J}=6.1 \mathrm{~Hz}, 3 \mathrm{H}), 1.16(\mathrm{~d}, \mathrm{~J}=6.0 \mathrm{~Hz}, 3 \mathrm{H}), 2.45-2.51(\mathrm{~m}, 2 \mathrm{H}), 3.52-3.75(\mathrm{~m}$, 5H overlapped with 2H, OH), $6.26(\mathrm{dt}, \mathrm{J}=15.9$ and $7.2 \mathrm{~Hz}, 1 \mathrm{H}), 6.47(\mathrm{~d}, \mathrm{~J}=15.9 \mathrm{~Hz}, 1 \mathrm{H}), 7.17-7.37$ (m, 5H); ${ }^{13} \mathrm{C}$ NMR: $\delta 22.1,22.8,34.8,63.4,71.1,72.6,78.4,125.8,126.1,126.9,128.3,132.2,137.3$. IR (liquid film): $3383 \mathrm{~cm}^{-1}$. Anal. Calcd for $\mathrm{C}_{15} \mathrm{H}_{22} \mathrm{O}_{3}: \mathrm{C}, 71.97 ; \mathrm{H}, 8.86$. Found: C, 72.10; H, 8.90. 


\section{General procedure for cyclization of compounds (1b,d) and (7a,b) with $\mathrm{PhSeCl}$}

To a solution of 7a (43 mg, $0.138 \mathrm{mmol})$ in $\mathrm{CH}_{2} \mathrm{Cl}_{2}(1.5 \mathrm{~mL})$ at $0{ }^{\circ} \mathrm{C} \mathrm{K}_{2} \mathrm{CO}_{3}(20 \mathrm{mg}, 0.138 \mathrm{mmol})$ was added. The resulting mixture was cooled to $-78{ }^{\circ} \mathrm{C}$, and $\mathrm{PhSeCl}(30 \mathrm{mg}, 0.151 \mathrm{mmol})$ dissolved in $\mathrm{CH}_{2} \mathrm{Cl}_{2}(1.5 \mathrm{~mL})$ was added via cannula. After $1 \mathrm{~h}$, the reaction was quenched adding water $(3 \mathrm{~mL})$. The mixture was warmed to $\mathrm{rt}$ and extracted with $\mathrm{CH}_{2} \mathrm{Cl}_{2}$. The organic layer was washed with saturated aqueous $\mathrm{NaCl}$, dried on anhydrous sodium sulfate and concentrated under reduced pressure. Column chromatography on silica gel, using light petrol-ethyl acetate (3:1) as eluent, gave compounds (8a) and (9a) (48 mg, yield $74 \%$, oil).

Compounds (2b) and (3b). (Yield 70\%; from light petrol-ethyl acetate 3:1, oil). ${ }^{1} \mathrm{H}$ NMR: $\delta$ 1.92-2.14 (m, 2H, 2b+3b), 2.80 (br s, OH), 3.08 (dd, J=10.4 and $10.4 \mathrm{~Hz}, 3 \mathbf{b}), 3.56(\mathrm{dd}, \mathrm{J}=11.0$ and $2.4 \mathrm{~Hz}, 2 \mathbf{b})$, 3.60-3.80 (m, 1H, 3b), $3.90(\mathrm{ddd}, \mathrm{J}=11.3,4.9$ and 1.7 Hz, 1H, 2b), 4.06-4.16 (m, 2H, 2b+3b), 4.27 (d, $\mathrm{J}=10.4 \mathrm{~Hz}, 3 \mathbf{b}), 4.75$ (d, J=11.0 Hz, 2b), 7.14-7.38 (m, 10H); ${ }^{13} \mathrm{C}$ NMR: $\delta 33.0(2 \mathbf{b}), 34.3(3 \mathbf{b}), 55.9(2 \mathbf{b})$, 59.9 (3b), 62.7 (2b), 65.4 (2b), 66.2 (3b), 70.1 (3b), 78.2 (2b), 89.5 (3b), 127.3, 127.9, 128.0, 128.1, 128.2, 128.3, 128.8, 129.0 (2b+3b), 135.0 (2b), 135.7 (3b), 139.2 (3b), 140.0 (2b). IR (liquid film): 3421 $\mathrm{cm}^{-1}$. Anal. Calcd for $\mathrm{C}_{17} \mathrm{H}_{18} \mathrm{O}_{2} \mathrm{Se}: \mathrm{C}, 61.26 ; \mathrm{H}, 5.44$. Found: $\mathrm{C}, 61.40 ; \mathrm{H}, 5.55$.

Compounds (2d) and (3d). These compounds were obtained as inseparable mixture together with the THF ring coming from the 5-exo cyclization. (yield 52\% 2d+3d, 13\% THF as determined by ${ }^{1} \mathrm{H}$ NMR; from light petrol-ethyl acetate 3:1, oil). ${ }^{1} \mathrm{H}$ NMR: $\delta 1.42(\mathrm{~d}, \mathrm{~J}=6.8 \mathrm{~Hz}, 3 \mathrm{H}, 2 \mathbf{d}$ or 3d), $1.45(\mathrm{~d}, \mathrm{~J}=6.5 \mathrm{~Hz}$, 3H, 2d or 3d), $1.46(\mathrm{~d}, \mathrm{~J}=6.7 \mathrm{~Hz}, 3 \mathrm{H}, \mathrm{THF}), 1.50-1.70(\mathrm{~m}, 1 \mathrm{H}, \mathbf{2 d}+3 \mathbf{d}+\mathrm{THF}), 1.93-2.55$ (m, 3H, 2d+3d+THF), 3.80-3.88 (m, 1H, THF), 4.19-4.71 (m, 3H, 2d+3d and 1H, THF), 5.27 (d, J=3.1 Hz, 1H, THF), 7.29-7.58 (m, 10H, 2d+3d+THF); ${ }^{13} \mathrm{C}$ NMR: $\delta 18.1(\mathrm{THF}), 21.0(\mathbf{2 d}$ or 3d), 21.8(2d or 3d), 26.4(THF), 27.6(THF), 30.7(2d or 3d), 31.4(2d or 3d), 32.7(2d or 3d), 33.6(2d or 3d), 49.4(THF), 54.7(2d or 3d), 54.8(2d or 3d), 68.2(THF), 73.5(THF), 75.7(2d or 3d), 76.1(2d or 3d), 81.3(2d or 3d), 82.1(2d or 3d), 126.5, 127.0, 127.1, 127.2, 127.3, 127.5, 127.8, 127.9, 128.0, 128.3, 128.4, 128.6, 129.2, 129.5, 134.1(THF), 135.2(2d or 3d), 135.4(2d or 3d), 140.8(THF), 140.9(2d or 3d), 141.2(2d or 3d). Anal. Calcd for $\mathrm{C}_{18} \mathrm{H}_{20} \mathrm{OSe}: \mathrm{C}, 65.25 ; \mathrm{H}, 6.08$. Found: C, 65.40; H, 6.28.

Compound (8a). ${ }^{1} \mathrm{H}$ NMR: $\delta 1.95$ (ddd, J=12.8, 12.8 and $\left.12.8 \mathrm{~Hz}, 1 \mathrm{H}\right), 2.22-2.28(\mathrm{~m}, 1 \mathrm{H}), 2.81$ (dt, $\mathrm{J}=12.8$ and $4.2 \mathrm{~Hz}, 1 \mathrm{H}), 3.38-3.49(\mathrm{~m}, 1 \mathrm{H}), 3.57-3.80(\mathrm{~m}, 3 \mathrm{H}), 4.42(\mathrm{~d}, \mathrm{~J}=10.7 \mathrm{~Hz}, 1 \mathrm{H}), 5.07-5.17$ (m, 1H), 7.10-7.67 (m, 13H), 8.00-8.08 (m, 2H); ${ }^{13} \mathrm{C}$ NMR: $\delta 37.8,43.4,62.2,68.5,80.1,84.9,127.7,128.0$, 128.2, 128.4, 128.6, 128.7, 128.8, 129.6, 133.3, 135.7, 138.8, 167.0. IR (liquid film): $3421,1718 \mathrm{~cm}^{-1}$. Anal. Calcd for $\mathrm{C}_{25} \mathrm{H}_{24} \mathrm{O}_{4} \mathrm{Se}$ : C, 64.24; H, 5.18. Found: C, 64.40; H, 5.13.

Compound (9a). ${ }^{1} \mathrm{H}$ NMR: $\delta$ 2.20-2.40 (m, 2H), 3.68-4.05 (m, 4H overlapped with 1H, OH), 4.97 (d, $\mathrm{J}=7.0 \mathrm{~Hz}, 1 \mathrm{H}), 5.32-5.39(\mathrm{~m}, 1 \mathrm{H}), 7.19-7.62(\mathrm{~m}, 13 \mathrm{H}), 8.00-8.06$ (m, 2H); IR (liquid film): 3386, 1716 $\mathrm{cm}^{-1}$. Anal. Calcd for $\mathrm{C}_{25} \mathrm{H}_{24} \mathrm{O}_{4} \mathrm{Se}: \mathrm{C}, 64.24 ; \mathrm{H}, 5.18$. Found: C, 64.42; H, 5.29. 
Compound (8b). (Yield 54\%; from light petrol-ethyl acetate 3:1, white solid, mp 97-99 ${ }^{\circ} \mathrm{C}$ ). ${ }^{1} \mathrm{H}$ NMR: $\delta 1.15(\mathrm{~d}, \mathrm{~J}=6.1 \mathrm{~Hz}, 6 \mathrm{H}), 1.73(\mathrm{dt}, \mathrm{J}=12.8$ and $10.6 \mathrm{~Hz}, 1 \mathrm{H}), 2.16$ (br s, 1H), 2.63 (dt, J=12.8 and 4.2 Hz, 1H), 3.22-3.39 (m, 2H), 3.44-3.54 (m, 1H), 3.63-3.84 (m, 3H), $4.32 \mathrm{~d}, \mathrm{~J}=10.6 \mathrm{~Hz}, 1 \mathrm{H}), 7.10-7.32$ (m, $10 \mathrm{H}) ;{ }^{13} \mathrm{C}$ NMR: $\delta 22.1,23.2,39.1,43.9,62.4,70.5,72.2,80.9,84.6,127.3,127.7,128.1,128.3,128.6$, 135.6, 139.3. IR (liquid film): $3483 \mathrm{~cm}^{-1}$. Anal. Calcd for $\mathrm{C}_{21} \mathrm{H}_{26} \mathrm{O}_{3} \mathrm{Se}: \mathrm{C}, 62.22 ; \mathrm{H}, 6.46$. Found: $\mathrm{C}$, 62.38; H, 6.55. Compound (9b) was obtained in mixture with $\mathbf{8 b}$. Some selected signals of $\mathbf{9 b}$ are: ${ }^{1} \mathrm{H}$ NMR: $\delta 2.05$ (ddd, J=13.8, 8.7 and 4.0 Hz, 1H), $2.20(\mathrm{dt}, \mathrm{J}=13.8$ and $4.9 \mathrm{~Hz}, 1 \mathrm{H}), 4.14-4.16(\mathrm{~m}, 1 \mathrm{H}), 5.07$ $(\mathrm{d}, \mathrm{J}=3.7 \mathrm{~Hz}, 1 \mathrm{H}) ;{ }^{13} \mathrm{C} \mathrm{NMR}: \delta 22.2,23.0,32.4,42.6,62.1,69.7,70.3,74.8,77.5,134.6,138.8$.

\section{General procedure for cyclization of compounds (7a,b) with 12}

To a solution of the chiral diselenide $(106 \mathrm{mg}, 0.247 \mathrm{mmol})$ in $\mathrm{CH}_{2} \mathrm{Cl}_{2}(3.8 \mathrm{~mL})$ cooled at $-78{ }^{\circ} \mathrm{C}$ was added a $1 \mathrm{M}$ solution of bromine in $\mathrm{CCl}_{4}(247 \mu \mathrm{L})$. After $5 \mathrm{~min}$, silver trifluoromethanesulfonate $(2 \mathrm{M}$ in $\mathrm{MeOH} ; 247 \mu \mathrm{L})$ was added. The resulting mixture was stirred for further 5 min then $7 \mathbf{b}(112.5 \mathrm{mg}, 0.45$ mmol) in $\mathrm{CH}_{2} \mathrm{Cl}_{2}(3.2 \mathrm{~mL})$ was added. After $1 \mathrm{~h}$ at $-78{ }^{\circ} \mathrm{C}$ a saturated aqueous solution of $\mathrm{NaHCO}_{3}$ was added. The reaction mixture was diluted with $\mathrm{CH}_{2} \mathrm{Cl}_{2}$, the organic phase separate, dried $\left(\mathrm{NaSO}_{4}\right)$ and concentrated under reduced pressure. Purification by flash chromatography gave the cyclized products.

Compound (10a). (Yield 30\%; from light petrol-ethyl acetate 2:1, oil) ${ }^{1} \mathrm{H}$ NMR: $\delta 0.89$ (t, J=7.3 Hz, 3H), 1.54-1.67 (m, 2H), 1.97-2.11 (m, 1H), $2.73(\mathrm{dt}, \mathrm{J}=12.5$ and $4.4 \mathrm{~Hz}, 1 \mathrm{H}), 3.46-3.79(\mathrm{~m}, 3 \mathrm{H}), 4.46(\mathrm{~d}$, $\mathrm{J}=10.6,1 \mathrm{H}), 4.91(\mathrm{dd}, \mathrm{J}=7.4$ and $5.5 \mathrm{~Hz}, 1 \mathrm{H}), 5.04-5.14(\mathrm{~m}, 1 \mathrm{H}), 7.00-7.59(\mathrm{~m}, 12 \mathrm{H}) ;{ }^{13} \mathrm{C}$ NMR: $\delta 10.2$, $31.3,38.1,43.9,62.1,68.4,74.4,80.3,84.5,126.2$, 127.6, 127.7, 128.2, 128.4, 128.6, 128.8, 129.6, 129.7, 133.4, 136.1, 138.7, 147.2, 165.7. IR (liquid film): 3460, $1716 \mathrm{~cm}^{-1}$. Anal. Calcd for $\mathrm{C}_{28} \mathrm{H}_{30} \mathrm{O}_{5} \mathrm{Se}: \mathrm{C}$, 64.00; H, 5.75. Found: C, 64.18; H, 5.88.

Compound (10b). (Yield 73\%; from light petrol-ethyl acetate 2:1, oil) ${ }^{1} \mathrm{H}$ NMR: $\delta 0.88(\mathrm{t}, \mathrm{J}=7.2 \mathrm{~Hz}, 3 \mathrm{H}$ ), $1.08(\mathrm{~d}, \mathrm{~J}=6.3 \mathrm{~Hz}, 3 \mathrm{H}), 1.11(\mathrm{D}, \mathrm{J}=6.3 \mathrm{~Hz}, 3 \mathrm{H}, 1.51-1.81$ (m, 3H), 2.43-2.50 (m, 3H); 3.29-3.45 (m, 3H), 3.58-3.78 (m, 3H), 4.31 (d, J=10.6 Hz, 1H), 4.87 (t, J=6.3 Hz, 1H), 6.98-7.04 (m, 1H), 7.13-7.47 (m, 8H);

${ }^{13} \mathrm{C}$ NMR: $\delta 10.2,22.0,23.1,31.2,39.2,43.9,62.2,70.5,72.0,74.1,81.1,84.2,126.0,126.6,126.8$, 127.3, 127.5, 128.1, 128.2, 128.4, 135.9, 139.0, 147.2. Anal. Calcd for $\mathrm{C}_{24} \mathrm{H}_{32} \mathrm{O}_{4} \mathrm{Se}: \mathrm{C}, 62.20 ; \mathrm{H}, 6.96$. Found: C, 62.30; H, 7.10.

\section{ACKNOWLEDGEMENTS}

Financial support from the University of Palermo (funds for selected research topics) and Italian MIUR within the National Research Project "Non-aromatic heterocycles in stereocontrolled processes" is gratefully acknowledged. We thank Prof. T. Wirth for comments. 


\section{REFERENCES AND NOTES}

1- T. Matsumoto, M. Katsuki, H. Jona, and K. Suzuki, J. Am. Chem. Soc., 1991, 113, 6982. See also refs. 4-7.

2- G. D. Daves and U. Hacksell, Prog. Med. Chem., 1985, 22, 1.

3- a) A. Wei, K. M. Boy, and Y. Kishi, J. Am. Chem. Soc., 1995, 117, 9432; b) I. Wang, P. Kóvac, P. Sinay, and C. P. J. Glaudemans, Carbohydr. Res., 1998, 308, 191; c) O. Tsuruta, H. Yuasa, S. Kurono, and H. Hashimoto, Bioorg. Med. Chem. Lett., 1999, 9, 807; d) G. Yang, R. W. Franck, R. Bittman, P. Samadder, and G. Arthur, Org. Lett., 2001, 3, 197; e) X. H. Cheng, N. Khan, and D. R. Mootoo, J. Org. Chem., 2000, 65, 2544.

4- a) M. H. D. Postema, 'C-Glycosides Synthesis', CRC Press, Boca Raton, 1995, p. 379; b) D. E. Levy and C. Tang, 'The Chemistry of C-Glycosides', Elsevier Science, Oxford, 1995, Vol. 13, p. 290; c) W. A. Remers, 'The Chemistry of Anti-Tumor Antibiotics', Wiley, New York, 1978.

5- For some recent approaches to C-glycosides, see: a) M. H. D. Postema and J. L. Piper, Org. Lett., 2003, 5, 1721; b) J. L. Chiara and E. Sesmilo, Angew. Chem., Int. Ed., 2002, 41, 3242; c) H. Liu, I. P. Smoliakova, and L. N. Koikov, Org. Lett., 2002, 4, 3895; d) I. Larrosa, P. Romea, F. Urpi, D. Balsells, J. Vilarrasa, M. Font-Bardia, and X. Solans, Org. Lett., 2002, 4, 4651; e) D. E. Paterson, F. K. Griffin, M. L. Alcaraz, and R. J. Taylor, Eur. J. Org. Chem., 2002, 1323; f) X. H. Cheng, N. Khan, and D. R. Mootoo, J. Org. Chem., 2000, 65, 2544.

6- For reviews on C-glycosides synthesis, see: a) M. H. D. Postema and D. Calimente, 'Glycochemistry: Principles, Synthesis and Applications', ed. by P. G. Wang, C. Bertozzi and Marcel Dekker, New York, 2000, Chapter 4, pp. 77-131; b) Y. Du and R. J. Lindhardt, Tetrahedron, 1998, 54, 9913; c) H. Togo, W. He, Y. Waki, and M. Yokoyama, Synlett, 1998, 700; d) F. Nicotra, Top. Curr. Chem., 1997, 187, 55; e) S. Hanessian, 'Preparative Carbohydrate Chemistry', ed. by S. Hanessian, Marcel Dekker, New York, 1997, pp. 505-542; f) J.-M. Beau and T. Gallagher, Top. Curr. Chem., 1997, 187, 1; g) C. Jaramillo and S. Knapp, Synthesis, 1994, 1.

7- Selected examples: a) B. Apsel, J. A. Bender, M. Escobar, D. E. Kaelin Jr., O. D. Lopez, and S. F. Martin, Tetrahedron Lett., 2003, 44, 1075; b) F. M. Hauser and X. Hu, Org. Lett., 2002, 4, 977; c) J. Ramnauth, O. Poulin, S. Rakhit, and S. P. Maddaford, Org. Lett., 2001, 3, 2013; d) K. A. Parker and Q. Ding, Tetrahedron, 2000, 56, 10255; e) B. Schmidt, Org. Lett., 2000, 2, 791; f) S. Futagami, Y. Ohashi, K. Imura, T. Hosoya, K. Ohmori, T. Matsumoto, and K. Suzuki, Tetrahedron Lett., 2000, 41, 1063; g) C. Fuganti and S. Serra, Synlett, 1999, 1241; h) G. Matsuo, Y. Miki, M. Nakata, S. Matsumura, and K. Toshima, J. Org. Chem., 1999, 64, 7101. i) T. Kuribayashi, N. Ohkawa, and S. Satoh, Tetrahedron Lett., 1998, 39, 4537.

8- a) S. J. Danishefsky, G. Phillips, and G. Guifolini, Carbohydr. Res., 1987, 171, 317; b) S. J. 
Danishefsky, B. J. Uang, and G. Quallich, J. Am. Chem. Soc., 1985, 107, 1285; c) R. R. Schmidt, W. Frick, B. Haag-Zeino, and S. Appara, Tetrahedron Lett., 1987, 28, 4045; d) D. J. Hart, G. H. Merriman, and D. G. J. Young, Tetrahedron, 1996, 52, 14437; e) D. J. Hart, L. Leroy, G. H. Merriman, and D. G. J. Young, J. Org. Chem., 1992, 57, 5671; f) M. A. Brimble, G. S. Pavia, and R. J. Stevenson, Tetrahedron Lett., 2002, 43, 1735.

9- C. Aprile, M. Gruttadauria, M. E. Amato, F. D’Anna, P. Lo Meo, S. Riela, and R. Noto, Tetrahedron, 2003, 59, 2241 and references cited therein.

10-a) P. L. Beaulieu and R. Déziel, 'Organoselenium Chemistry', ed. By T. G. Back, Oxford University Press, Oxford, 1999, pp 35-66; b) T. Wirth, Tetrahedron, 1999, 55, 1; c) M. Tiecco, L. Testaferri, C. Santi, C. Tomassini, F. Marini, L. Bagnoli, and A. Temperini, Chem. Eur. J., 2002, 8, 1118; d) L. Uehlin, G. Fragale, and T. Wirth, Chem. Eur. J., 2002, 8, 1125 and references cited therein.

11- D. J. Hart, S. Patterson, and A. Zakarian, Heterocycles, 2000, 52, 1025.

12- C. Aprile, M. Gruttadauria, P. Lo Meo, S. Riela, and R. Noto, Heterocycles, 2002, 57, 293.

13- D. F. Taber, J. H. Green, W. Zhang, and R. Song, J. Org. Chem., 2000, 65, 5436.

14- V. S. Martin, J. M. Ode, J. M. Palazon, and M. A. Soler, Tetrahedron: Asymmetry, 1992, 3, 573.

15- M. Caron and K. B. Sharpless, J. Org. Chem., 1985, 50, 1557.

16- T. Wirth, Angew. Chem., Int. Ed. Engl., 1995, 34, 1726.

17- a) M. Spichty, G. Fragale, and T. Wirth, J. Am. Chem. Soc., 2000, 122, 10914; b) X. Wang, K. N. Houk, M. Spichty, and T. Wirth, J. Am. Chem. Soc., 1999, 121, 8567; c) T. Wirth, G. Fragale, and M. Spichty, J. Am. Chem. Soc., 1998, 120, 3376.

18- Determined by ${ }^{1} \mathrm{H}$ NMR spectrum.

19- Reagent (12) was not able to perform the kinetic resolution of $\mathbf{7 b}$. We detected, in the reaction mixture, the tetrahydropyran coming from the minor enantiomer.

20- In the literature are reported only two examples of the use of chiral organoselenium electrophile for 6-endo cyclization of achiral substrates: R. Déziel and E. Malenfant, J. Org. Chem., 1995, 60, 4660; M. Tiecco, L. Testaferri, F. Marini, S. Sternativo, L. Bagnoli, C. Santi, and A. Temperini, Tetrahedron: Asymmetry, 2001, 12, 1493. 